\title{
Assessment of soil loss vulnerability in data-scarce watersheds in southern Brazil
}

\section{Avaliação da vulnerabilidade à perda de solos em uma bacia hidrográfica com dados escassos no sul do Brasil}

\author{
Alice Alonzo Steinmetz ${ }^{1 *}$, Felício Cassalho², Tamara Leitzke Caldeira', \\ Vinícius Augusto de Oliveira ${ }^{3}$, Samuel Beskow', Luis Carlos Timm
}

\author{
1 Universidade Federal de Pelotas/UFPEL, Pelotas, RS, Brasil \\ 2 Instituto Nacional de Pesquisas Espaciais/INPE, São José dos Campos, SP, Brasil \\ 3 Universidade Federal de Lavras/UFLA, Lavras, MG, Brasil \\ ${ }^{4}$ Universidade Federal de Pelotas/UFPEL, Capão do Leão, RS, Brasil \\ *Corresponding author: alicesteinmetz@gmail.com \\ Received in October 1, 2018 and approved in November 16, 2018
}

\begin{abstract}
Soil erosion is currently one of the main concerns in agriculture, water resources, soil management and natural hazards studies, mainly due to its economic, environmental and human impacts. This concern is accentuated in developing countries where the hydrological monitoring and proper soil surveys are scarce. Therefore, the use of indirect estimates of soil loss by means of empirical equations stands out. In this context, the present study proposed the assessment of the Revised Universal Soil Loss Equation (RUSLE) with the aid of Geographical Information Systems (GIS) and remote sensing for two agricultural watersheds in southern Rio Grande do Sul - Brazil. Among all RUSLE factors, LS showed the closest patterns to the local when compared to the total annual soil loss, thus being a good indicator $\mathrm{t}$ of risk areas. The total annual soil loss varied from 0 to more than $100 \mathrm{t} \mathrm{ha}^{-1} \mathrm{yr}^{-1}$, with the vast majority (about $65 \%$ of the total area) classified from slight to moderate rates of soil loss. The results estimated according to RUSLE indicated that over $10 \%$ of the study area presented very high to extremely high soil loss rates, thus requiring immediate soil conservation practices. The present study stands out as an important scientific and technical support for practitioners and decision-makers, being probably the first of its nature applied to extreme southern Brazil.
\end{abstract}

Index terms: Soil erosion; revised universal soil loss equation; geographical information systems; remote sensing.

\section{RESUMO}

A erosão do solo é atualmente uma das principais preocupações nos estudos de agricultura, recursos hídricos, manejo do solo e desastres naturais, principalmente devido aos impactos econômicos, ambientais e humanos associados à erosão. Esta situação é agravada nos países em desenvolvimento, onde o monitoramento hidrológico e os levantamentos adequados do solo são escassos. Portanto, destaca-se o uso de estimativas indiretas de perda de solo por meio de equações empíricas. Neste contexto, o presente estudo propôs a aplicação da Equação Universal de Perdas de Solo Revisada (RUSLE) com o auxílio de Sistemas de Informações Geográficas (SIG) e Sensoriamento Remoto para duas bacias hidrográficas agrícolas no Rio Grande do Sul - Brasil. Entre todos os fatores RUSLE, o LS apresentou a distribuição espacial mais próxima quando comparada à perda total anual de solo, sendo um bom indicador de áreas de risco. A perda total anual de solo variou de 0 a mais de $100 \mathrm{t} \mathrm{ha}^{-1} \mathrm{ano}^{-1}$, sendo a grande maioria (cerca de 65\% da área total) classificada de leve a moderado níveis de perda de solo. Mais de $10 \%$ da área de estudo apresenta níveis altos a extremamente altos de perda de solo, exigindo intervenções imediatas. O presente estudo destaca-se como uma importante ferramenta para praticantes e tomadores de decisão, sendo o primeiro estudo de sua natureza no extremo sul do Brasil.

Termos para indexação: Erosão do solo; equação universal da perda de solo revisada; sistemas de informações geográficas; sensoriamento remoto.

\section{INTRODUCTION}

Due to the strong human, economic, environmental, and social dependence, soil is considered one of the most important natural resources (Abdo; Salloum, 2017a). Soil erosion has been historically treated as one of the most common and relevant environmental threats $(\mathrm{Xu} ; \mathrm{Xu}$;
Meng, 2012). According to Perović et al. (2013), soil erosion is defined as a complex time and space varying mechanism influenced by different factors (e.g. land use and cover, local climate and morphologic characteristics) which affect the detachment of soil particles and even their water or wind driven transport (Abdo; Salloum, 2017b). 
Water erosion is a natural and irreversible geomorphological phenomenon that results in land degradation and loss of soil fertility (Jiang et al., 2015). According to Beskow et al. (2009), water erosion can be classified into: i) rill erosion, in which the soil is detached and transported by concentrated flow, and ii) interrill erosion caused by the soil detachment resulting from the impact of water droplets, which is transported along with surface runoff. As a consequence of the ever-growing population and the intensification of anthropogenic activities, such as agricultural malpractices, urbanization, deforestation, fire, mining, overgrazing, overstocking, and use of pesticides (Kisan et al., 2016; Napoli et al., 2016), water erosion has become a severe and globally widespread environmental hazard (Napoli et al., 2016; Abdo; Salloum, 2017a).

Natural hazards caused by soil erosion are grouped as on-site (e.g. changes of soil physical and chemical properties) or off-site such as. damage to hydraulic structures downstream, diversion of streams, deposition on riverbeds and reservoirs, and floods (Kisan et al., 2016). Some strategies are adopted to mitigate the impacts of soil erosion in a properly managed watershed (Naqvi et al., 2013). However, such management practices are directly dependent on information related to soil loss estimations and mapping (Ganasri; Ramesh, 2016), which are not frequently available to the watershed of interest (Markose; Jayappa, 2016).

Ideally, soil losses are measured on standard plots, but such direct approach is usually neither labor nor time efficient (Pan; Wen, 2014). Moreover, the availability of such data is limited or inexistent, which hampers the implementation of an efficient watershed management (Markose; Jayappa, 2016). Even though direct soil loss measurements are indispensable for a sustainable land use management, indirect estimates obtained according to water erosion models have become a widely accepted approach (Xu; Xu; Meng, 2012). By definition, soil erosion models include several complex interactions among driving mechanisms (Pan; Wen, 2014). These prediction models can be classified into empirical, physical, and conceptual models (Fakhri et al., 2014).

Empirical models are easily applied due to their simple structures and reliability (Chen; Zha, 2016). Several empirical models have been discussed in the literature, such as the: Bureau of Land Management (BLM), Ephemeral Gully Erosion Model (EGEM), Erosion Potential Method (EPM), Erosion Productivity Impact Calculator (EPIC), Food and Agriculture Organization Model, Geoland 2 (G2), Musgrave Model, Pacific
Southwest Interagency Committee (PSIAC), Revised Universal Soil Loss Equation (RUSLE), Scalogram Model, Soil Loss Estimation for Southern Africa (SLEMSA), Stehlik Model, Universal Soil Loss Equation (USLE) (Fakhri et al., 2014).

In contrast to empirical models, physically-based models describe the set of mechanisms controlling the water erosion process, thus better representing the physical world (Beskow et al., 2009; Chen; Zha, 2016). Among these models, Perović et al. (2013), Fakhri et al. (2014), and Chen and Zha (2016) highlight the Areal Non-point Source Watershed Environment Response Simulation (ANSWERS), Chemical Runoff and Erosion from Agricultural Management System (CREAMS), European Erosion Simulation (EUROSEM), Griffth University Erosion System Template (GUEST), EROSION 3D, Kinematic Erosion Simulation (KINEROS), Limburg Soil Erosion Model (LISEM), Modular Soil Erosion System (MOSES), Pan-European Soil Erosion Risk Assessment (PESERA), and Water Erosion Prediction Project (WEEP). Conceptual (i.e. semi-empirical) models have elements from empirical and physical models (Fakhri et al., 2014). These authors point out the following conceptual models: Agricultural Non-Point Source Model (AGNPS), Large Scale Catchment Model (LASCAM), Simulator for Water Resources in Rural Basin-Soil and Water Assessment Tool (SWRRB-SWAT), Topographical Model (TOPMODEL), and Water and Tillage Erosion Model (WATEM).

The USLE family models developed by Wischmeier and Smith (1965) and afterwards revised by Renard et al. (1991) (Revised Universal Soil Loss Equation - RUSLE) and modified by Williams and Berndt (1977) (Modified Universal Soil Loss Equation - MUSLE) remain as the most worldwide used tool for estimating spatially distribution of soil erosion due their comprehensive structure and wide availability of input data to be applied along with GIS and remote sensing (Abdo; Salloum, 2017a; Perović et al., 2013). Differently than its predecessors, the USLE family may be used if its factors are accurately estimated, having as main goals to: i) represent long term average soil loss by means of a single number, ii) predict soil loss from local meteorological and soil data, and iii) be free from geographically oriented bases (Renard et al., 1997). It should be mentioned that the USLE family models only account for rill and interrill soil losses, thus neglecting gully, tillage, and wind erosion (Ozcan et al., 2008). Despite this disadvantage, applications of these models have been found on national, regional, and basin scales (Jiang et al., 2015). 
Although these models have been proposed in a developed country there is a large amount of available data, they have been used to estimate soil loss in developing countries. Recent applications are found in Brazil (Beskow et al., 2009; Oliveira et al., 2014), India (Kisan et al., 2016), Serbia (Perović et al., 2013), Syria (Abdo; Salloum, 2017a), and Turkey (Ozcan et al., 2008), reinforcing the importance of such models in developing countries, where the use of more complex models is limited due to the lack of adequate input data (Perović et al., 2013).

The present study proposes the application of the RUSLE coupled with GIS and remote sensing techniques in two data-scarce watersheds in southern Brazil: Fragata river watershed (FRW) and Pelotas river watershed (PRW). These watersheds are part of the Mirim-São Gonçalo watershed (MSGW), which is a transboundary watershed with a drainage area of approximately $62,250 \mathrm{~km}^{2}$, where $47 \%$ is located in Brazil and the remaining 53\% in Uruguayan territory. MSGW plays a fundamental economic role in the south of Rio Grande do Sul state as it is the main source of water for agriculture, public supply and transportation. In addition, according to the Brazilian Atlas of Natural Disasters (CEPED, 2013), MSGW has a high incidence of natural disasters due to floods which may aggravate the erosion processes. In this context, the main objectives are to: i) estimate the total annual soil loss, ii) identify the most susceptible locations with respect to soil erosion in order to aid decision-makers in the proposal of watershed and soil management practices in the FRW and PRW.

\section{MATERIAL AND METHODS}

\section{Study area}

The annual soil loss was estimated for two datascarce watersheds located in Southern Brazil, the Fragata river watershed (FRW) and Pelotas river watershed (PRW). These watersheds are the main tributaries of an important transboundary river watershed, the Mirim-São Gonçalo watershed (MSGW). The MSGW is located between the latitudes $31^{\circ} 30^{\prime} \mathrm{S}$ and $34^{\circ} 30^{\prime} \mathrm{S}$ and longitudes $52^{\circ} \mathrm{W}$ and $56^{\circ} \mathrm{W}$, with a drainage area of approximately $62,250 \mathrm{~km}^{2}$, in which $47 \%$ and $53 \%$ are located in the Brazilian and Uruguayan territories, respectively (Figure 1).

The irrigated rice production stands out as the main agricultural activity in the Brazilian territory of the MSGW, playing an important role in both economic and social sectors, followed by soybeans, wheat, and corn. In addition, it also contains preservation areas of ecological systems such as the Taim Ecological Station, which is recognized by the United Nations Educational Scientific and Cultural Organization (UNESCO) as a Biosphere Reserve.

The FRW and PRW are located in southern Rio Grande do Sul State (Figure 1), having a drainage area of $132 \mathrm{~km}^{2}$ and $368 \mathrm{~km}^{2}$, respectively. According to the Köppen classification method, the regional climate is classified as $\mathrm{Cfa}$, and has a humid oceanic climate with hot summer; the mean annual temperature is $17.8^{\circ} \mathrm{C}$, mean annual minimum and maximum temperatures range from 13.8 to $22.9{ }^{\circ} \mathrm{C}$, while mean annual precipitation corresponds to $1,367 \mathrm{~mm}$.

\section{The Revised Universal Soil Loss Equation (RUSLE)}

The RUSLE model (Equation 1) estimates the longterm annual average soil loss under specific conditions, such as rill and inter-rill erosion (Renard; Freimund, 1994). Inter-rill erosion occurs when soil particles are detached by raindrops and transported by shallow overland flows, whereas rill erosion is the detachment and transport of soil particles by concentrated flows. This detached soil is then transported and delivered as sediment downstream (Silva; Montenegro; Santos, 2012). To evaluate the potential soil loss and its distribution in the FRW and PRW, the RUSLE model was applied within a GIS environment with the aid of map algebra.

$\mathrm{A}=\mathrm{R} \times \mathrm{K} \times \mathrm{LS} \times \mathrm{C} \times \mathrm{P}$

where $\mathrm{A}$ is average annual soil loss $\left(\mathrm{t} \mathrm{ha}^{-1} \mathrm{yr}^{-1}\right), \mathrm{R}$ refers to rainfall erosivity factor (MJ mm ha- $\mathrm{h}^{-1} \mathrm{yr}^{-1}$ ), $\mathrm{K}$ corresponds to soil erodibility factor $\left(\mathrm{t} \mathrm{h} \mathrm{MJ}^{-1} \mathrm{~mm}^{-1}\right)$, LS is hillslope length and steepness factor (dimensionless), C corresponds to cover management factor (dimensionless), and $\mathrm{P}$ is the erosion control practice factor (dimensionless).

\section{Rainfall erosivity ( $R)$}

Rainfall erosivity $(R)$ represents the potential of rainfall to cause erosion in a given unprotected soil. The $\mathrm{R}$ factor, which is influenced by rainfall intensity and raindrop size (Beskow et al., 2009), takes into account both total precipitation and raindrops kinetic energy. It is calculated by the product of rainfall kinetic energy and the maximum 30-minute rainfall intensity $\left(\mathrm{EI}_{30}\right)$ (Pandey; Chowdary; Mal, 2007; Wischmeier; Smith, 1978). The $R$ factor is often determined from rainfall intensity information whenever such data are available (Bagherzadeh, 2014). Due to lack of detailed rainfall records, the rainfall erosivity map of the present study was generated based on geostatistical procedures in accordance with recommendations of Mello et al. (2013). 

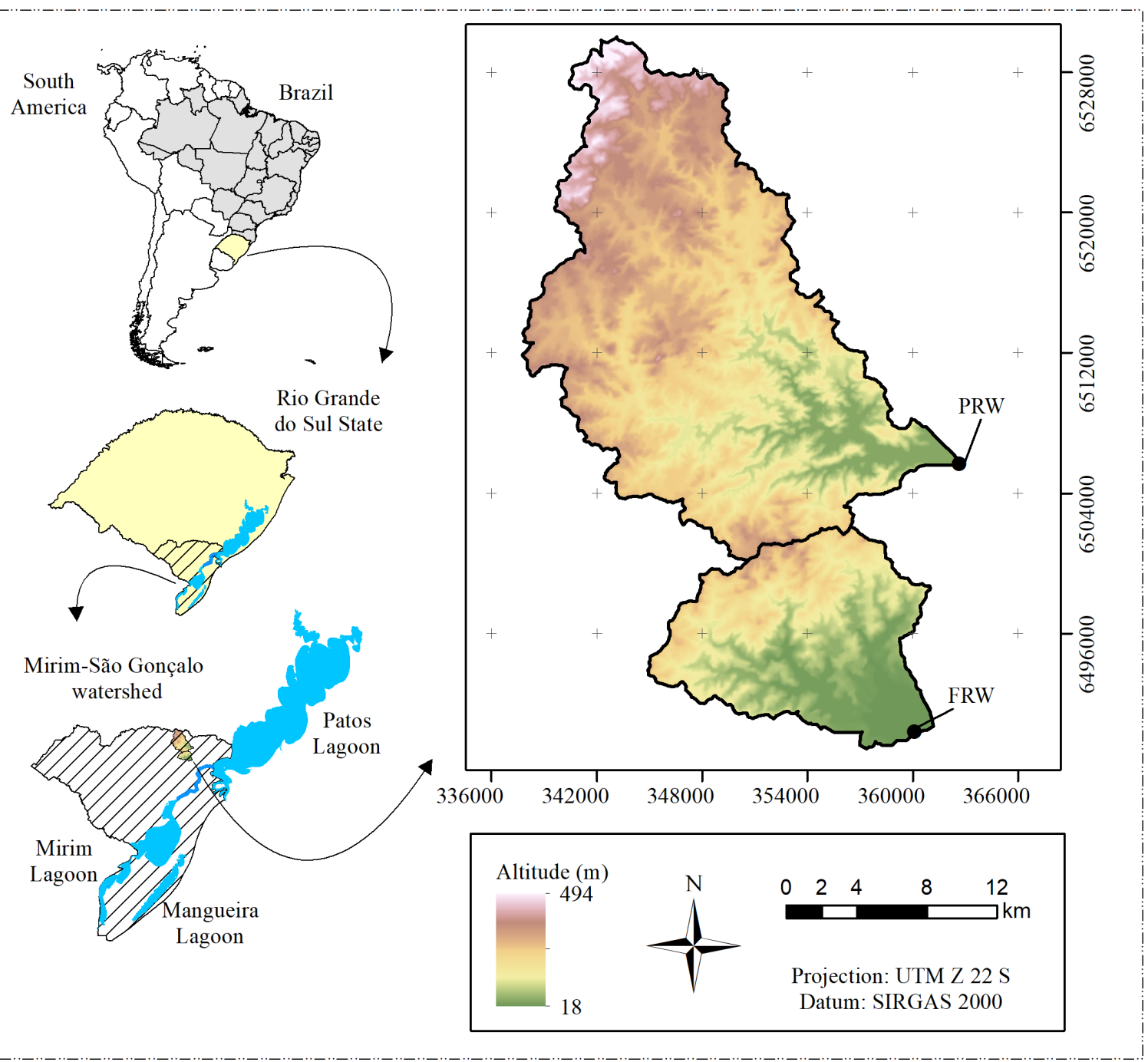

Figure 1: Location of the Mirim-São Gonçalo watershed in the Brazil, the study area and digital elevation models of Fragata and Pelotas river watersheds.

Thus, the multivariate geographical model proposed by Mello et al. (2013) for Southern Brazil was applied (Equation 2). This multivariate model allows the estimation of the mean annual rainfall erosivity from latitude, longitude and altitude of each cell, characterizing the $\mathrm{R}$ factor in a distributed manner. The model for estimating the $\mathrm{R}$ factor in Southern Brazil region is given by (Mello et al., 2013):

$R=2610770-60.44 \times A+98839 \times L O-1114.68$

$\times L A^{2}+938.47 \times L O^{2}-1.185 \times A$

$\times L O+1.1885 \times L A^{2} \times \mathrm{LO}^{2}+0.01494 \times \mathrm{LA}^{2}$

$\times L O^{3}$ where $\mathrm{R}$ is average annual erosivity (MJ mm ha ${ }^{-1} \mathrm{~h}^{-1} \mathrm{yr}^{-1}$ ), A is altitude (m), LA corresponds to latitude and $\mathrm{LO}$ refers to longitude, both in negative decimal degrees.

$R$ values may be highly variable worldwide, with the highest values found for tropical regions. In a literature review Oliveira, Wendland and Nearing (2012) observed that $\mathrm{R}$ values for tropical regions were found to be as low as 2,980 $\mathrm{MJ} \mathrm{mm} \mathrm{ha}^{-1} \mathrm{~h}^{-1} \mathrm{yr}^{-1}$ (in Honduras) and as high as 33,500 MJ mm ha ${ }^{-1} \mathrm{~h}^{-1} \mathrm{yr}^{-1}$ in the Australian tropics. While, in the temperate zones the $\mathrm{R}$ values tend to be lower, ranging from $50 \mathrm{MJ} \mathrm{mm} \mathrm{ha-1} \mathrm{h}^{-1} \mathrm{yr}^{-1}$ in Chile to less than 12,000 in the United States. A classification of R factor 
values for Brazilian conditions adopted Carvalho (2008) is presented in Table 1 .

Table 1: $\mathrm{R}$ factor values classes according to Carvalho (2008).

\begin{tabular}{cc}
\hline Erosivity & Erosivity class \\
\hline $0-2,452$ & Low erosivity \\
$2,452-4,905$ & Medium erosivity \\
$4,905-7,357$ & Medium-strong erosivity \\
$7,357-9,810$ & Strong erosivity \\
$>9,810$ & Very strong erosivity \\
\hline
\end{tabular}

\section{Soil erodibility (K)}

The K factor corresponds to the soil erodibility or the soil intrinsic susceptibility to erosion, which reflects the spatial variability of possible soil erosion depending on its structural and compositional characteristics (Abdo; Salloum, 2017b). This factor can be determined through experiments carried out in field plots; however, field trials for estimating the $\mathrm{K}$ factor are expensive and time consuming. Therefore, it is commonly obtained from predefined estimates (Beskow et al., 2009).

The spatial distribution of the main soil types found in the study area, as proposed by Cunha, Silveira and Severo (2006), is depicted in Figure 2. This map was used as a reference to define the spatially distributed $\mathrm{K}$ factor.

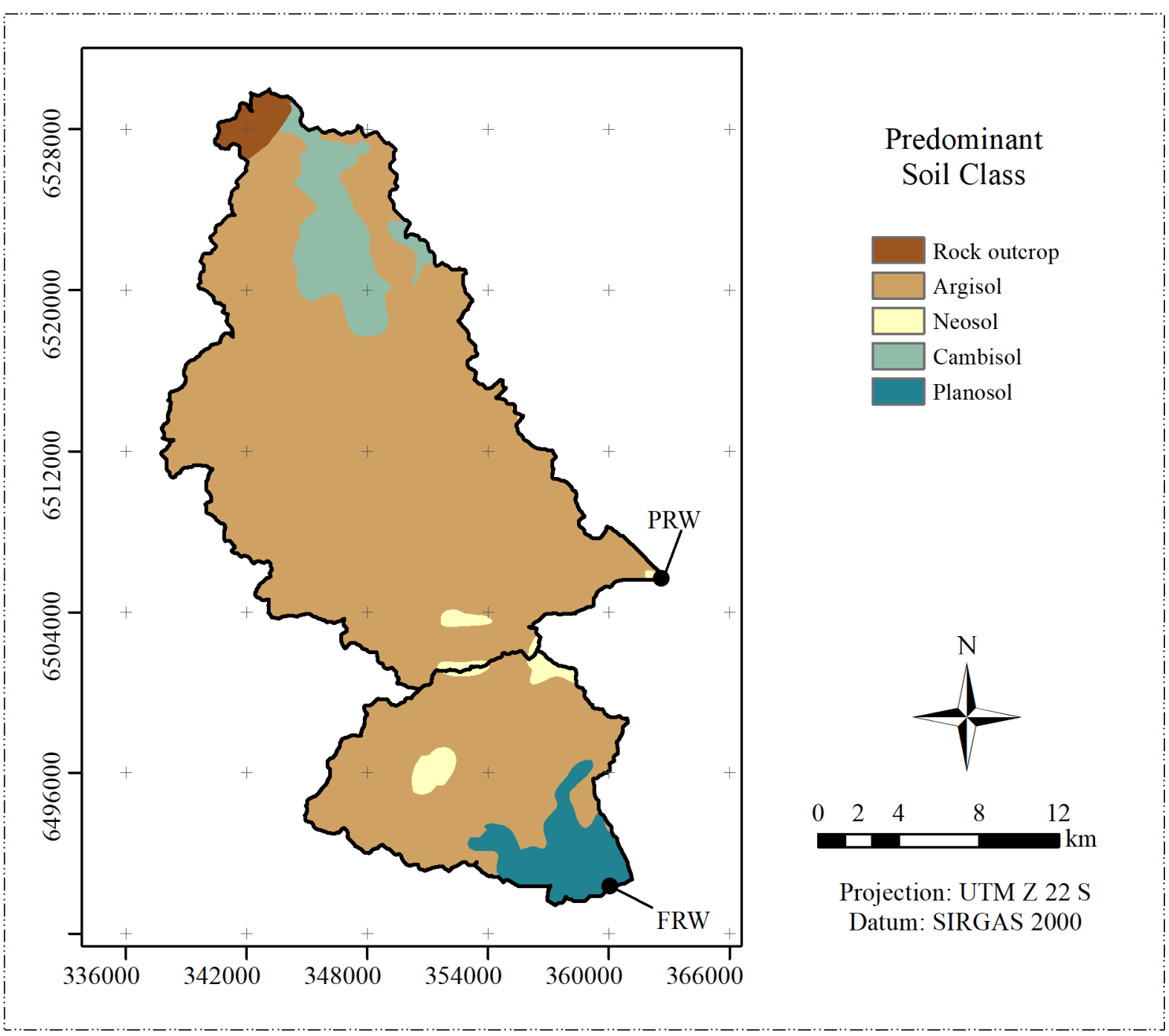

Figure 2: Main soil classes in the Fragata (FRW) and Pelotas (PRW) river watersheds, adapted from Cunha, Silveira and Severo (2006). 
Based on the main soil classes (Figure 2) and on the published literature reporting soil erodibility values for soil classes observed in different regions of Brazil, the $\mathrm{K}$ values used in this study are presented in Table 2.

Table 2: $\mathrm{K}$ factor values adopted in this study.

\begin{tabular}{|c|c|c|}
\hline Soil class & 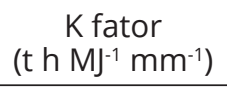 & Reference \\
\hline Neosol & 0.0569 & Marques et al. (1997) \\
\hline Planosol & 0.0570 & $\begin{array}{l}\text { Silva, Paiva and Santos } \\
\text { (2009) }\end{array}$ \\
\hline Cambisol & 0.0508 & $\begin{array}{c}\text { Araújo, Salviano and } \\
\text { Neto (2011) }\end{array}$ \\
\hline Argisol & 0.0330 & Sá et al. (2004) \\
\hline
\end{tabular}

\section{Topographic factor (LS)}

The topographic factor (LS) represents the intrinsic impact of the terrain on soil erosion with respect to the direct surface runoff movement on a hillslope; this representation is considered by means of the slope steepness (S) and slope length (L) factors (Beskow et al., 2009; Biswas; Pani, 2015). Thus, the LS factor (Equation 3) depends not only on steepness and length of slope but also on the flow expected to occur on land and later to be concentrated in the water courses (Saygın et al., 2014). LS-factor layer was derived from the Digital Elevation Model (DEM) with a spatial resolution of $30 \mathrm{~m}$. The LS equation considered in this study was presented by Abdo and Salloum (2017a):

$L S=\left(\frac{F A \times C S}{22.13}\right)^{0.4} \times\left(\frac{\sin (S)}{0.0896}\right)^{1.3}$

where FA is the flow accumulation expressed as the number of grid cells, CS is the raster spatial resolution (m), and S is the slope (degrees). All the parameters of this equation are represented by means of a raster map, i.e. there is a value for each $30-\mathrm{m}$ cell of the map.

\section{Cover management factor (C)}

Vegetation plays an important role in protecting soil from erosion by dissipating the kinetic energy of raindrops and reducing runoff speed. The cover management factor (C) is the ratio of soil loss observed in a land covered by a specific vegetation by the corresponding soil loss under continuous fallow vegetation (Ozsoy et al., 2012). It ranges from 0 to 1 according to the vegetation cover such that greater values represent larger disaggregation of soils due to rainfall droplet impact and surface runoff (Oliveira et al., 2014). $\mathrm{C}$ values were obtained from the land use map (Figure 3 ) combined with published literatures regarding such factor for different regions of Brazil (Table 3).

The land use map (Figure 3) was generated from the Landsat 5 images provided by the National Institute for Space Research (INPE). These images were interpreted with the aid of a supervised spectral classification using the maximum likelihood method. This interpretation took into account 200 known land use field samples, which were obtained through Global Positioning System (GPS).

\section{Erosion control practice factor $(P)$}

The erosion control practice factor $(\mathrm{P})$ is the ratio between soil erosion under a particular support practice and that observed uphill and downhill slope cultivation (Pandey; Chowdary; Mal, 2007). The P factor varies from 0 to 1 and expresses the potential of the surface and management practices to reduce soil erosion (Oliveira et al., 2014). The lower the $P$ factor, the more effective the conservation practice is in terms of reduction in the soil erosion (Bagherzadeh, 2014). The $P$ factor was considered to be 1 for both FRW and PRW, since no erosion control practices were identified. Several studies have also considered this factor as 1 due to the lack of significant erosion control practices, such as Abdo and Salloum (2017a), Bera et al. (2017), Beskow et al. (2009), Oliveira et al. (2014) and Ozsoy et al. (2012).

\section{RESULTS AND DISCUSSION}

According to Naqvi et al. (2013), R is one of the most important factors influencing the soil loss rate. As shown in Figure 4, the study area presents low variability in terms of $\mathrm{R}$ values $\left(7,640\right.$ to $\left.8,750 \mathrm{MJ} \mathrm{mm} \mathrm{ha} \mathrm{m}^{-1} \mathrm{~h}^{-1} \mathrm{yr}^{-1}\right)$. Despite the low variability, the $\mathrm{R}$ values observed for the study region are considerably higher when compared to those reported in studies conducted worldwide. In a study in the Mashhad plain - Iran, Bagherzadeh (2014) found R values ranging from 107 to $146 \mathrm{MJ} \mathrm{mm} \mathrm{ha} \mathrm{m}^{-1} \mathrm{~h}^{-1} \mathrm{yr}^{-1}$; Jiang et al. (2015) got $\mathrm{R}$ values for the Lower Jinsha River Basin - China from 923.5 to 2,534.9 MJ mm ha ${ }^{-1} \mathrm{~h}^{-1} \mathrm{yr}^{-1}$; Ganasri and Ramesh (2016) estimated maximum $\mathrm{R}$ values up to 4,711.4 MJ mm ha-1 $\mathrm{h}^{-1} \mathrm{yr}^{-1}$ for the Nethravathi Basin in southern India. However, higher values might be expected when considering Brazilian conditions. On conducted a study in the Rio Verde basin, situated in southeastern Brazil, Oliveira et al. (2014) observed R values ranging 
from 7,086 to $15,115 \mathrm{MJ} \mathrm{mm} \mathrm{ha}^{-1} \mathrm{~h}^{-1} \mathrm{yr}^{-1}$. Also, Durães, varying from 5,244 to 6,736 $\mathrm{MJ} \mathrm{mm} \mathrm{ha}^{-1} \mathrm{~h}^{-1} \mathrm{yr}^{-1}$ in the Coelho Filho and Oliveira (2016) determined R values Upper Iguaçu River Basin, Southern Brazil.

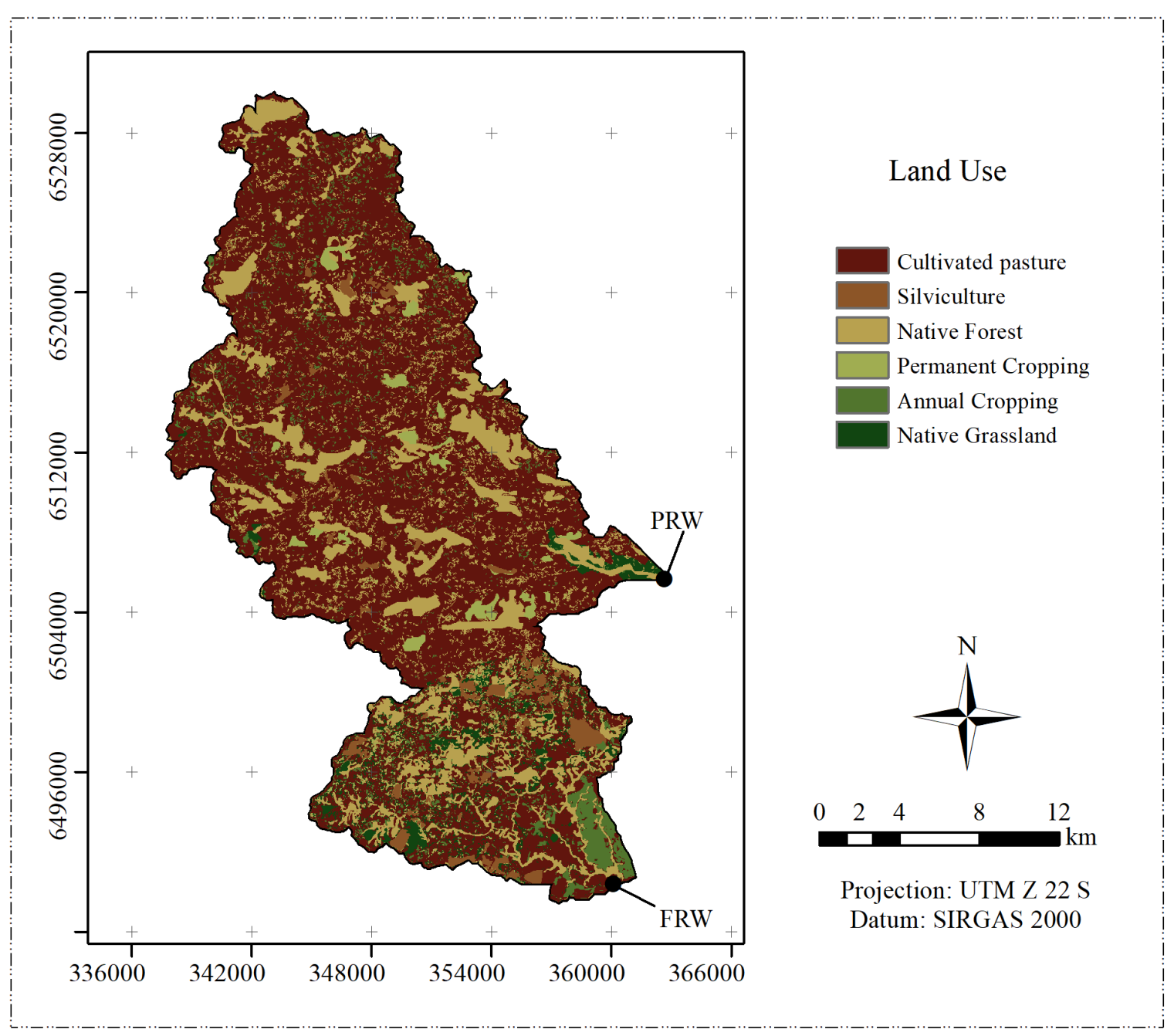

Figure 3: Land use maps for the Fragata (FRW) and Pelotas (PRW) river watersheds.

Table 3: C factor values for the each land use in the FRW and PRW.

\begin{tabular}{ccc}
\hline Land use & C factor & Reference \\
\hline Native forest & 0.012 & Farinasso et al. (2006) \\
Planted forest & 0.032 & Adapted from Panagos et al. (2015) \\
Annual cropping & 0.2 & Adapted from Panagos et al. (2015) \\
Cultivated pasture & 0.01 & Tomazoni et al. (2005) \\
Native grassland & 0.01 & Tomazoni et al. (2005) \\
Permanent cropping & 0.02 & Adapted from Panagos et al. (2015) \\
\hline
\end{tabular}




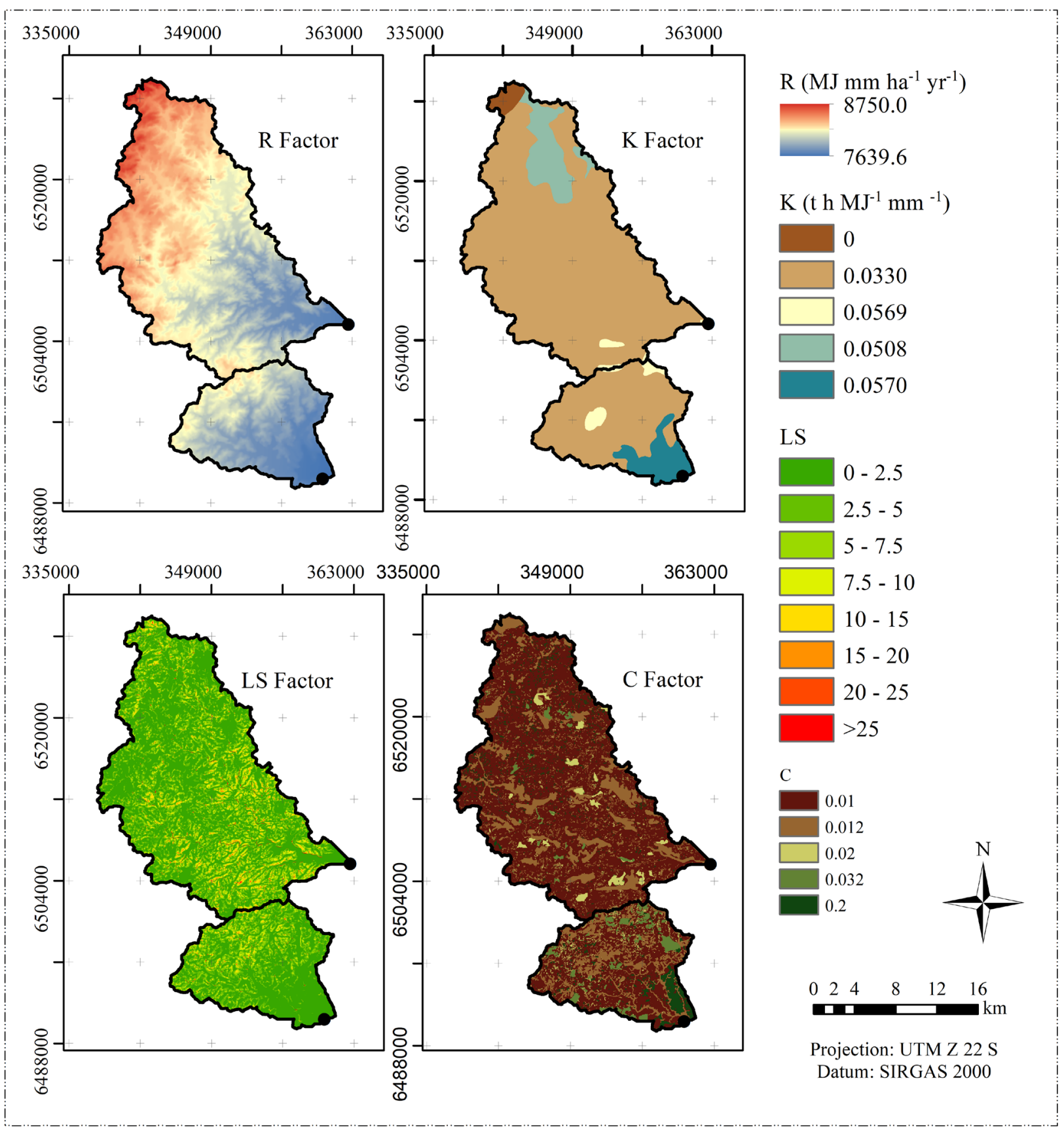

Figure 4: Rainfall erosivity (R), Soil erodibility (K), Topographic (LS) and Conservation support practice (P) factors for Fragata and Pelotas river watershed.

The $\mathrm{R}$ values presented in Figure 4 also corroborate Mello et al. (2013) who considered datasets from 733 rain gauges when estimating spatially distributed rainfall erosivity for Brazil. The aforementioned authors found a high variability in terms of $R$ values in the country, ranging from 2,224 in the driest areas (Brazilian northeast) to more than 23,000 MJ mm ha- $\mathrm{h}^{-1} \mathrm{yr}^{-1}$ in the Amazon rainforest. It was found that the FRW had predominance of lower R 
values, while PRW presented larger R values, especially in the headwater region. In addition, it should be pointed out the importance in considering the spatial distribution of $\mathrm{R}$, as the application of a mean value for the entire study area has been a common practice. Nonetheless, the entire study area's erosivity may be classified as Strong erosivity according to Carvalho (2008).

Figure 4 also presents the spatial distribution of the soil erodibility factor $(\mathrm{K})$ which follows the previously mentioned map of soil classes (Figure 2). The lowest value of the $\mathrm{K}$ factor was attributed to the region of PRW covered by rock outcrop. For this area, a $\mathrm{K}$ value of 0 was attributed, since there is no structured soil and therefore no soil erosion. A low $\mathrm{K}$ value was also set to the most frequent soil class found in the study area (Argissol). Sá et al. (2004) estimated Argisols erodibility based on soil desagregations by ultrasound analysis and recommended the use of $\mathrm{K}$ values of $0.033 \mathrm{th} \mathrm{MJ}^{-1} \mathrm{~mm}^{-1}$. Smaller portions of the watersheds having Neosols and Cambisols are also found in higher altitudes. These less developed soils present higher $\mathrm{K}$ values (Table 2) according to Marques et al. (1997) and Araújo, Salviano and Neto (2011), who carried out studies in Brazil. The predominance of Argisols over Neosols and Cambisol may lower annual soil losses in the highlands, which may be considered the most vulnerable regions due to their greater $\mathrm{R}$ and slope factor (S) values. The higher values of $K$ are found in the flattest regions of FRW, where there is predominance of Planosols. As adopted by Silva, Paiva and Santos (2009) for a watershed situated between the Brazilian States of Pernambuco and Alagoas, a K value of 0.057 was set to the Planosols in the present study.

A special attention should be given to the topographic factor, since it characterizes the surface runoff speed, in other words, it is a good indication of soil erosion risk (Beskow et al., 2009). The spatial distribution of the LS factor (Figure 4) indicates that about 98 and $96 \%$ of the FRW and PRW, respectively, had values less than 10. According to Beskow et al. (2009), areas with LS values greater than 10 can be considered as high vulnerability to erosion, thus conservation practices are generally encouraged in order to reduce runoff energy gain due to the topography. The greatest LS values are not concentrated but rather spatially distributed in both watersheds, reinforcing the need of a broad watershed erosion management.

Relative to the cover management factor (C), there was a predominance of low values (Figure 4) associated with cultivated pasture and forested areas (Figure 3). Greater LS values were mostly observed in areas with cultivated pasture and areas covered by native forest, thereby implying in the reduction of the resulting annual soil loss when applying Equation 1. Moreover, there was a concentration of higher $\mathrm{C}$ values in the southern region of FRW as a result of annual cropping. These areas also presented a concentration of low R and LS values (Figure 4), which may reduce the resulting soil loss rates. On the other hand, since most of this area is covered by Planosols, where the greatest soil erodibility values are found, a rather spatially heterogeneous soil erosion vulnerability is observed (Figure 5).

Figure 5 illustrates the spatial distribution of the soil erosion vulnerability in FRW and PRW resulting from the interaction among the aforementioned RUSLE factors (Figure 4). Several soil erosion classification methods are presented in the literature. Among these methods, those proposed by Abdo and Salloum (2017a) for Syria, and by Bagherzadeh (2014) for Iran should be highlighted. The qualitative classification considered in the present study was proposed by Beskow et al. (2009) for Brazilian conditions. This method divides the soil loss rates into classes ranging from "slight" to "extremely high" according to soil erosion vulnerability (Table 4).

There is a predominance of slight soil erosion vulnerability in both watersheds (Table 4). Soil loss rates less than $2.5 \mathrm{tha}^{-1} \mathrm{yr}^{-1}$ are spatially distributed throughout the study area (Figure 5). However, there are concentration areas in the PRW headwater where rock outcrop is found in the lowlands and in some areas covered by native forests. The percentage area classified as slight soil erosion vulnerability is followed by the moderate class in both watersheds (Table 4).

On analyzing Table 4, one can infer that a large part of FRW and PRW $(\sim 47 \%)$ is estimated to have an average annual soil loss of less than $5 \mathrm{t} \mathrm{ha}^{-1} \mathrm{yr}^{-1}$, which may be considered as low erosion levels (Pandey; Chowdary; Mal, 2007). Several factors might have caused low erosion rates in most of the study area. These low soil erosion rates can be partially attributed to the low $\mathrm{C}$ values (Beskow et al., 2009) in both watersheds, which were experienced in areas under cultivated pasture, silviculture and native forests.

Soil losses between 5 and $11 \mathrm{tha}^{-1} \mathrm{yr}^{-1}$ may limit agricultural productivity (Abdo; Salloum, 2017a), thus requiring awareness for those areas with moderate, high or extremely high soil loss vulnerability. These researchers stressed out that rapid interventions by means of control measures and maintenance are required if these erosion rates occur. 


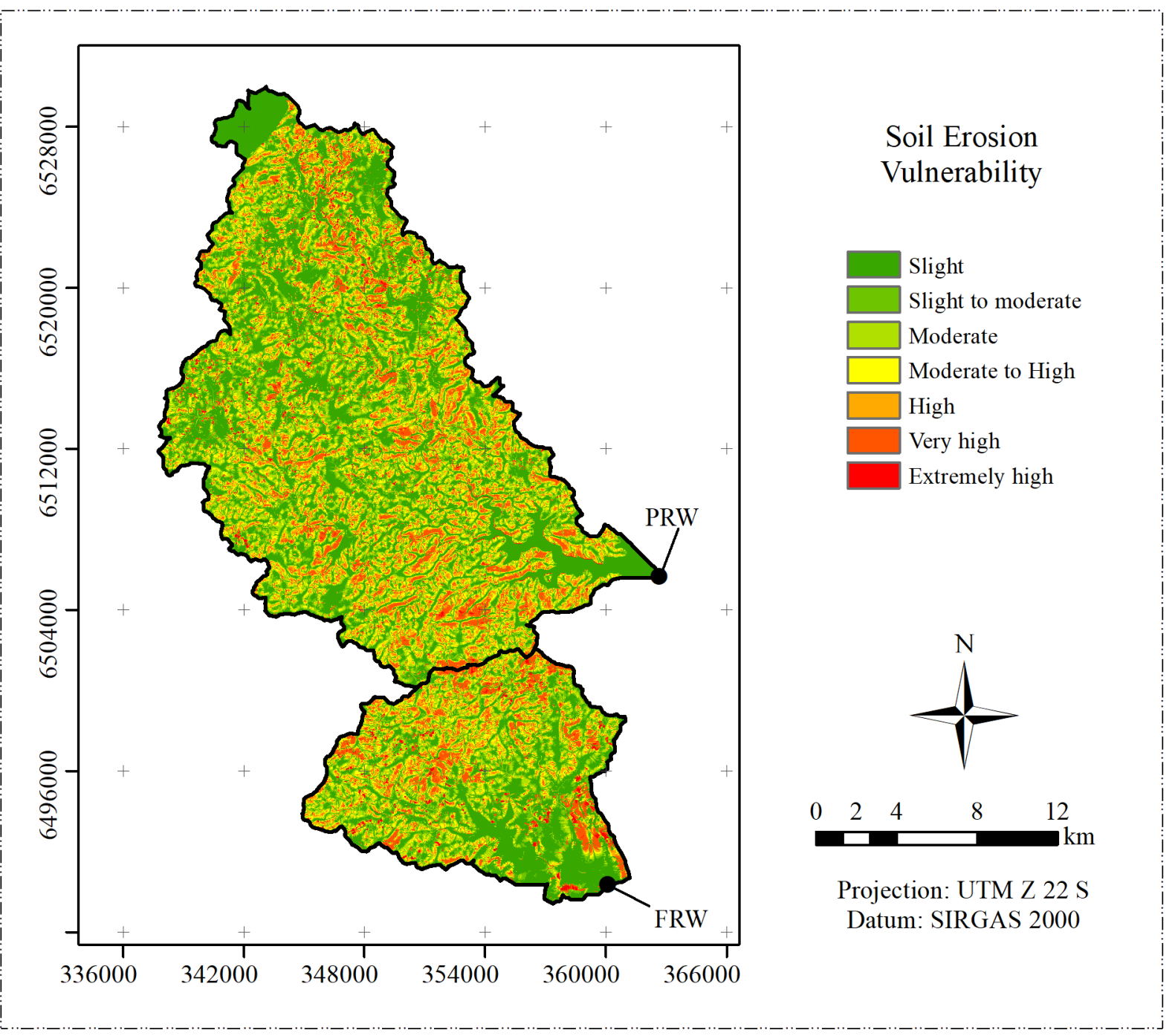

Figure 5: Map of soil erosion vulnerability for Fragata (FRW) and Pelotas (PRW) river watersheds.

Table 4: Soil erosion vulnerability according to categories suggested by Beskow et al. (2009), as well as the percentage of the area occupied by each class.

\begin{tabular}{cccc}
\hline Soil loss $\left(\mathrm{t} \mathrm{ha}^{-1} \mathrm{yr}^{-1}\right)$ & Vulnerability & FRW (\%) & PRW (\%) \\
\hline $0-2.5$ & Slight & 34.8 & 35.3 \\
$2.5-5$ & Slight to moderate & 11.9 & 11.8 \\
$5-10$ & Moderate & 18.0 & 18.8 \\
$10-15$ & Moderate to High & 11.4 & 12.3 \\
$15-25$ & High & 10.7 & 11.8 \\
$25-100$ & Very high & 11.2 & 8.5 \\
$>100$ & Extremely high & 2 & 1.5 \\
\hline
\end{tabular}


Overall, the soil loss vulnerability in the study area can be associated with the LS factor. This study made it possible to observe that: i) high soil erosion vulnerability occurs in the Planosols whenever it is associated with annual cropping; ii) very high vulnerability coincides with high LS values even when land cover is native forest; and iii) extremely high vulnerability is associated with annual cropping as well as high LS values. In addition, soil class may have also influenced high values of soil loss (Table 5).

As presented in Table 5, Neosols have the largest percentage of high and very high soil loss vulnerability. According to Figure 2 this soil class is mostly found in the headwaters of both watersheds which correspond to areas of high R and LS factors. On the other hand, Planosols, which are found for the lowest altitude areas of FRW, are the least vulnerable with more than $63 \%$ of its area being classified as slight vulnerability despite the fact that most of its area is covered by annual cropping and cultivated pasture (Figure 3). Argisol and Cambisols present similar results, with Cambisols found in the high altitude areas of PRW (Figure 1,2), being more vulnerable than the former.

The results presented in Figure 5, Table 4 and Table 5 stand out as an important tool for water resources and soil erosion managers in the region, as well as policy makers, allowing not only the identification of vulnerable areas but also the spatially distributed estimated amounts of annual soil loss in FRW and PRW. Simulations considering different erosion control practices (P) and land cover (C) may also aid decision-makers on building future scenarios in order to determine the most suitable management practices. In this context, the use of Universal Soil Loss family equations gains even more importance in developing countries due to the scarcity in soil loss data or even reliable input data for physicallybased soil erosion models (Beskow et al., 2009; Ozcan et al., 2008).

Despite the importance of such approach, some limitations must be highlighted. As a parametric equation, uncertainties in the input values play an important role in the final soil loss. Parameters K and $\mathrm{C}$, for example, are derived from studies that may not be the most adequate to the study area, since they were estimated for other regions of Brazil. In addition, factor $\mathrm{C}$ was derived from satellite imagery classification, which by itself contains intrinsic errors and generalizations. On the other hand, the factors $\mathrm{R}$ and LS were derived from equations instead of published values. However, due to their spatial dependence, in terms of latitude, longitude, altitude, and slope, there might be a considerable amount error propagation not only by the equations but also by the DEM used in the present study.

Table 5: Soil erosion vulnerability for each soil class.

\begin{tabular}{cccccc}
\hline Vulnerability & Rock outcrop (\%) & Neosol (\%) & Planosol (\%) & Cambisol (\%) & Argisol (\%) \\
\hline Slight & 100.0 & 19.7 & 63.1 & 28.8 & 33.4 \\
Slight to moderate & 0.0 & 3.0 & 9.5 & 9.5 & 12.5 \\
Moderate & 0.0 & 8.9 & 8.0 & 16.1 & 19.9 \\
Moderate to High & 0.0 & 10.7 & 4.3 & 12.3 & 12.7 \\
High & 0.0 & 18.0 & 4.5 & 15.3 & 11.7 \\
Very high & 0.0 & 36.5 & 8.2 & 14.5 & 8.4 \\
Extremely high & 0.0 & 3.3 & 2.4 & 3.6 & 1.4 \\
\hline
\end{tabular}




\section{CONCLUSIONS}

The study proposes that the use of GIS and RUSLE constitute an effective approach for estimating the magnitude and spatial distribution of soil erosion rates in Southern Brazil. Soil loss was estimated to the entire study area, ranging from 0 to more than $100 \mathrm{tha}^{-1} \mathrm{yr}^{-1}$. The most susceptible areas were found in areas with the greatest LS values, therefore reinforcing the need of conservation practices in order to promote sustainable agricultural practices in such steep terrains. The results found in this study stand out as one of the pioneer studies of its nature for the FRW and PRW, thus playing an important role for the regional soil and water resources management. Future studies should focus on direct field measurements of soil loss in the Fragata and Pelotas river watershed to validate the results estimated according to the RUSLE.

\section{REFERENCES}

ABDO, H.; SALLOUM, J. Spatial assessment of soil erosion in Alqerdaha basin (Syria). Modeling Earth Systems and Environment, 3(26):7, 2017a.

ABDO, H.; SALLOUM, J. Mapping the soil in Marqya basin: Syria using RUSLE model in GIS and RS techniques. Environmental Earth Sciences, 76(3):114, 2017b.

ARAÚJO, F.; SALVIANO, A.; NETO, M. Estimativa da erodibilidade de latossolos do Piauí. Scientia Plena, 7(10):6, 2011.

BAGHERZADEH, A. Estimation of soil losses by USLE model using GIS at Mashhad plain, Northeast of Iran. Arabian Journal of Geosciences, 7(1):211-220, 2014.

BERA, A. Assessment of soil loss by universal soil loss equation (USLE) model using GIS techniques: A case study of Gumti River Basin, Tripura, India. Modeling Earth Systems and Environment, 3(1):29, 2017.

BESKOW, S. et al. Soil erosion prediction in the Grande River Basin, Brazil using distributed modeling. Catena, 79(1):4959, 2009.

BISWAS, S.; PANI, P. Estimation of soil erosion using RUSLE and GIS techniques: A case study of Barakar River basin, Jharkhand, India. Modeling Earth Systems and Environment, 1(4):42, 2015.

CARVALHO, N. O. Hidrossedimentologia Prática. Editora Interciência, 2008. v.2, 599p.

CENTRO UNIVERSITÁRIO DE ESTUDOS E PESQUISAS SOBRE DESASTRES (CEPED). Atlas brasileiro de desastres naturais 1991 a 2012: Volume Rio Grande do Sul. CEPEDUFSC, 2013. 185p.

CHEN, S.; ZHA, X. Evaluation of soil erosion vulnerability in the Zhuxi watershed, Fujian Province, China. Natural Hazards, 82(3):1586-1607, 2016.

CUNHA, N. G.; SILVEIRA, R. J. C.; SEVERO, C. R. C. Solos e terras do planalto Sul-Rio-Grandense e planícies costeiras. Pelotas: Embrapa Clima Temperado, 2006. 42p. (Embrapa Clima Temperado. Circular técnica, 55).

DURÃES, M. F.; COELHO FILHO, J. A. P.; OLIVEIRA, V. A. D. Water erosion vulnerability and sediment delivery rate in upper Iguaçu river basin-Paraná. Revista Brasileira de Recursos Hídricos, 21(4):728-741, 2016.

FAKHRI, M. et al. Flow and sediment transport modeling in rivers. ESLAMIAN, S. Handbook of Engineering Hydrology. CRC press, v.2, 2014. p.233-275.

FARINASSO, M. et al. Avaliação qualitativa do potencial de erosão laminar em grandes áreas por meio da EUPS utilizando novas metodologias em sig para os cálculos dos seus fatores na região do Alto Parnaíba-Pi-MA. Revista Brasileira de Geomorfologia, 7(2):73-85, 2006.

GANASRI, B. P.; RAMESH, H. Assessment of soil erosion by RUSLE model using remote sensing and GIS - A case study of Nethravathi Basin. Geoscience Frontiers, 7(6):953-961, 2016.

JIANG, L. et al. Estimation of soil erosion in some sections of Lower Jinsha River based on RUSLE. Natural Hazards, 76(3):1831-1847, 2015.

KISAN, M. V. et al. Remote sensing and GIS based assessment of soil erosion and soil loss risk around hill top surface mines situated in Saranda Forest, Jharkhand. Journal of Water and Climate Change, 9(2):68-82, 2016.

MARKOSE, V. J.; JAYAPPA, K. S. Soil loss estimation and prioritization of sub-watershed of Kali River basin, Karnataka, India, using RUSLE and GIS. Environmental Monitoring and Assessment, 188(4):225-241, 2016.

MARQUES, J. J. et al. Adequação de métodos indiretos para estimativa da erodibilidade de solos com horizonte B textural no Brasil. Revista Brasileira de Ciência do Solo, 21(3):447-456, 1997.

MELLO, C. R. et al. Erosividade mensal e anual da chuva no Estado de Minas Gerais. Pesquisa Agropecuária Brasileira, 42(4):537-545, 2007.

MELLO, C. R. et al. Multivariate models for annual rainfall erosivity in Brazil. Geoderma, 202:88-102, 2013. 
NAPOLI, M. et al. Simulation of field-measured soil loss in Mediterranean hilly areas (Chianti, Italy) with RUSLE. Catena, 145:246-256, 2016.

NAQVI, H. R. et al. Multi-temporal anual soil loss risk mapping employing Revised Universal Soil Loss Equation (RUSLE) model in Nun Nadi Watershedm Uttrakhand (India). Arabian Journal of Geosciences, 6(40):4045-4056, 2013.

OLIVEIRA, P. T. S.; WENDLAND, E.; NEARING, M. A. Rainfall erosion in Brazil: A review. Catena, 100:139-147, 2012.

OLIVEIRA, V. et al. Soil erosion vulnerability in the Verde river basin, southern Minas Gerais. Ciência e Agrotecnologia, 38(3):262-269, 2014.

OZSOY, G. et al. Determination of soil erosion risk in the Mustafakemalpasa river basin, Turkey, using the revised universal soil loss equation, geographic information system, and remote sensing. Environmental Management, 50(4):679-694, 2012.

OZCAN, A. U. et al. Use of USLE/GIS technology integrated with geostatistics to assess soil erosion risk in different land uses of Indagi Mountain Pass - Çankırı, Turkey. Environmental Geology, 53(8):1731-1741, 2008.

PAN, J.; WEN, Y. Estimation of soil erosion using RUSLE in Caijiamiao watershed, China. Natural Hazards, 71(3):21872205, 2014.

PANAGOS, P. et al. Estimating the soil erosion covermanagement factor at the European scale. Land Use Policy, 48:38-50, 2015.

PANDEY, A.; CHOWDARY, V. M.; MAL, B. C. Identification of critical erosion prone areas in the small agricultural watershed using USLE, GIS and remote sensing. Water Resources Management, 21(4):729-746, 2007.

PEROVIĆ, V. et al. Spatial modeling of soil erosion potential in a mountainous watershed of South-eastern Serbia. Environmental Earth Sciences, 68(1):115-128, 2013.

RENARD, K. G. et al. Predicting Soil Erosion by Water: A guide to conservation planning with the Revised Universal Soil Loss Equation (RUSLE). U.S. Department of Agriculture, Agriculture Handbook No. 703, 1997, $404 p$.
RENARD, K. G.; FREIMUND, J. R. Using monthly precipitation data to estimate the R-factor in the revised USLE. Journal of Hydrology, 157(1-4):287-306, 1994.

RENARD, K. G. et al. RUSLE - Revised universal soil loss equation. Journal of Soil and Water Conservation, 46(1):30-33, 1991.

SÁ, M. A. C. et al. Estimativa da erodibilidade pela desagregação por ultra-som e atributos de solos com horizonte B textural. Pesquisa Agropecuária Brasileira, 39(7):691-699, 2004.

SAYGIN, S. D. et al. The combined RUSLE/SDR approach integrated with GIS and geostatistics to estimate annual sediment flux rates in the semi-arid catchment, Turkey. Environmental Earth Sciences, 71(4):1605-1618, 2014.

SILVA, R. M.; MONTENEGRO, S. M. G. L.; SANTOS, C. A. G. Integration of GIS and remote sensing for estimation of soil loss and prioritization of critical sub-catchments: A case study of Tapacurá catchment. Natural Hazards, 62(3)953-970, 2012.

SILVA, R. M.; PAIVA, F. M.; SANTOS, C. A. Análise do grau de erodiblidade e perdas de solo na bacia do Rio Capiá baseado em SIG e sensoriamento remoto. Revista Brasileira de Geografia Física, 2(1):26-40, 2009.

TOMAZONI, J. C. et al. A sistematização dos fatores da EUPS em SIG para quantificação da erosão laminar na bacia do rio Anta Gorda (PR). Revista Eletrônica de Geografia, 3(1):01-21, 2005

$X U$, L.; XU, X.; MENG, X. Risk assessment of soil erosion in different rainfall scenarios by RUSLE model coupled with Information Diffusion Model: A case study of Bohai Rim, China. Catena, 100:74-82, 2012.

WILLIAMS, J. R.; BERNDT, H. D. Sediment yield prediction based on watersehd hydrology. Transactions of the American Society of Agricultural and Biological Engineers, 20(6):1100-1104, 1977.

WISCHMEIER, W. H.; SMITH, D. D. Predicting rainfall erosion losses from cropland east of the Rocky Mountain. Washington, DC: ARS/USDA, 1965. 49p.

WISCHMEIER, W. H.; SMITH, D. D. Predicting rainfall erosion losses: A guide to conservation planning. Washington: USDA, 1978, 58p. 